\title{
Production Systems, Genetic Diversity and Genes Associated with Prolificacy and Milk Production in Indigenous Goats of Sub-Saharan Africa: A Review
}

\author{
Simon Patrick Baenyi ${ }^{1,2 *}$, Joseph Owino Junga², Christian Keambou Tiambo ${ }^{3,4}$, \\ Ahadi Bwihangane Birindwa1,5, Katcho Karume1, Getinet Mekuriaw Tarekegn ${ }^{3,6}$, \\ Joel Winyo Ochieng2
}

\footnotetext{
${ }^{1}$ Department of Animal Production, Université Evangélique en Afrique, Bukavu, The Democratic Republic of the Congo

${ }^{2}$ Department of Animal Production, University of Nairobi, Nairobi, Kenya

${ }^{3}$ Bioscience Eastern and Central Africa-International Livestock Research Institute, Nairobi, Kenya

${ }^{4}$ Centre for Tropical Livestock Genetics and Health-International Livestock Research Institute (CTLGH-ILRI), Nairobi, Kenya

${ }^{5}$ Regional Universities Forum for Capacity Building in Agriculture (RUFORUM), Wandegeya, Kampala, Uganda

${ }^{6}$ Department of Animal Breeding and Genetics, Swedish University of Agricultural Sciences Uppsala, Uppsala, Sweden

Email: ‘baenyipatrick@gmail.com, joseph.junga@uonbi.ac.ke,C.Tiambo@cgiar.org, Adjibir@yahoo.fr, kkatcho@yahoo.com,

yafetgeti-net@gmail.com, jochieng@uonbi.ac.ke
}

\begin{abstract}
How to cite this paper: Baenyi, S.P., Junga, J.O., Tiambo, C.K., Birindwa, A.B., Karume, K., Tarekegn, G.M. and Ochieng, J.W. (2020) Production Systems, Genetic Diversity and Genes Associated with Prolificacy and Milk Production in Indigenous Goats of Sub-Saharan Africa: A Review. Open Journal of Animal Sciences, 10, 735-749. https://doi.org/10.4236/ojas.2020.104048
\end{abstract}

Received: July 27, 2020

Accepted: October 19, 2020

Published: October 22, 2020

Copyright $\odot 2020$ by author(s) and Scientific Research Publishing Inc. This work is licensed under the Creative Commons Attribution International License (CC BY 4.0).

http://creativecommons.org/licenses/by/4.0/

\section{(c) (i) Open Access}

\begin{abstract}
Goats are one of the oldest domesticated animal species widely distributed in the world playing an important role in the food production system in Sub-Saharan African Region (SSAR). Due to their multiple uses (milk production, meat, fiber and hides) and adaptation aptitudes to ecological conditions, goats produce and contribute positively to farmers' socio-economy status in various production systems. This review aimed at giving a summary overview on the goat's production systems characteristics, the genetic diversity and the candidate genes affecting reproductive and milk production performances in goat breeds in SSAR. It has been observed that traditional livestock production system with communal grazing system is the most used in goat keeping in SSAR. The geographical locations play an important role in the relationships between goat's distributions in the region. At the same time, goats might have been differentiated and isolated one to others due to the wide geographic range, the diversify climate and the topography in the region. Among the six worldwide known haplogroups of goat (A, B, C, D, G and $\mathrm{F}$ ), haplogroup $\mathrm{A}$ is the most representative in SSAR. However, haplogroup $\mathrm{G}$ and $\mathrm{B}$ can be found in some goat populations in some countries in east (Kenya and Ethiopia) and south parts of Africa. This review reveals that
\end{abstract}


little is known on the candidate genes associated with prolificacy and milk production traits in indigenous goat breeds in the region. That observation suggests the importance of assessing candidate genes associated with economic traits in the populations of goat in SSAR.

\section{Keywords}

Gene, Prolificacy, Milk Production, Sub-Saharan African Region

\section{Introduction}

Goats are among the first domesticated animals; they are largely distributed around the world playing a major role in food production systems in many developing countries [1] contributing significantly to household income [2]. Goats are appreciated by farmers and consumers due to their multiple uses (milk production, meat, fiber and hides) and adaptation aptitudes. However, in many parts of the world, they are exploited without proper knowledge on their genetic diversity and without genetic improvement programs necessarily being established [3]. The investigation of genetic diversity at molecular level has been proposed as a valuable complement and sometimes proxy to phenotypic diversity of local breeds and is presently considered as one of the Food and Agricultural Organization's priorities for breed characterization [4].

Genetic diversity is considered to affect species' and populations' sustainability in long term. Its determination constitutes an important accomplishment of conservation preferences as soon as the important management programs are required to maintain genetic diversity in livestock species. These programs should focus on the comprehensive of the information regarding the production systems, the populations' structure which includes different genetic sources diversity within and among breeds [5]. Therefore, molecular characterization based on different methods and molecular markers are most used to determine animal genetic diversity. Markers such as microsatellites DNA (SSRs) for the genetic variability studies and evolutionary relationships of closely related populations have been developed according to the important level of polymorphism, random repartition across all the genomes, the neutrality with consideration to selection [6].

At the second kidding, litter size is often a precious indicator to discover whether a goat is fecund. However, it seems like a crucial and complex economic character within the goat industry [7] [8] [9] [10]. The number of kids per parity seems to be under the control of different genes and factors [11] and cannot be increased with traditional selection methods due to low heritability.

Therefore, identification of genetic markers linked to loci responsible for prolificacy would be useful in selection. As the major genes associated with reproduction and milk production performances have been identified and provided, they can contribute to the animal improvement program considering mark- 
er-assisted selection (MAS).

Information on reproduction systems of goat including reproductive characteristics of some goats breeds in Africa have been given [12] in a review paper but this information becomes old and should be updated. This review aims to give an overview on the production system, the genetic diversity and the signatures of selection or candidate genes associated with prolificacy and milk production in indigenous goat populations in Sub-Saharan African Region (SSAR).

\section{Origin and Domestication of Goats}

The domestic goat (Capra hircus) is generally considered to have been first domesticated from the wild bezoar goat (Capra aegragrus) somewhere in the Fertile Crescent of the Near East some 10.000 - 11.000 years ago. Ever since that time, goats have fulfilled a vital economic, cultural and religious role in many human civilizations. A collaborative research effort that integrates genetics and archaeology has vastly expanded the ability not only to detect the context, locations and timing of initial goat domestication but also to trace the migratory trajectories used by humans to spread this farm animal worldwide [13].

Many divergences were observed on the origin of goat according to research conducted by different authors. Following a district lineage 3 and a divergent lineage 3 founded in Slovenia and in Switzerland, three regions including Carpathian Mountain, Balkans of Romania and Southern France have been considered in contrast as the different origin of goats [14] [15] [16]. Therefore, [17] suggested that Levant and Mehrgarh should be two ancient centers for goat domestication. The DNA analysis of the ancient goat from Inner Mongolia region was genetically closed to modern Chinese goats suggesting China as possible domestication center specifically for sub-haplogroups B1 and B2 [18]. According to the findings on the mitochondrial DNA based on the hypervariable (HVI) region of ancient goat, the Central Zagros seems to possibly play an important role in $\mathrm{Ca}$ pra hircus domestication [19].

The goats (Capra hircus) which have been firstly domesticated for meat production are one of the oldest domesticated animal species and probably the first ruminant after domestication of wolf [20].

\section{Production Systems of Goats in SSAR}

Goat production in general contributes largely to livelihoods of low- and medium-income farmers in Sub-Saharan African countries (tropics, dry areas) [21].

In these areas, farming systems have evolved to cope with the formidable constraints imposed by harsh natural and economic conditions by adapting integrated crop/livestock production strategies. Due to its almost exclusive extensive nature, goat production relies mainly on grazing on communal lands hardly providing the minimum nutrient requirements in Asia, Africa and Latin America, due to overstocking and degradation. Special strategies for breeding should be understood for the promotion of the conservation and improvement of adap- 
tability, water use efficiency and suitability under harsh climatic conditions thought the production systems are becoming semi-intensive [22]. Two types of production systems including modern and traditional livestock production systems have been distinguished in Sub-Saharan African countries based on factors of production. Goats as other ruminants are kept in both. Therefore, modern systems compared to traditional systems considered as the familial production system, require a large capital and employ substantial amounts of hired labor [22]. It was demonstrated in Sub-Saharan African zone that generally; traditional livestock systems were far more prevalent than modern systems [23]. However, this production system is characterized by high mortality risks, especially for kids (27.4\% in arid area and $33.1 \%$ in semi-arid area) [24].

In west Africa region, traditional keeping system based on natural rangeland use as feed resources and free roaming is the most common system in the regions employed for goats raising [25]. Different goat breeds populations found in this region were characterized by long leg and were mainly raised for meat, skin and milk production. In Nigeria and Niger, Red Sokoto goat breed also known as Maradi goat was used for the good quality of its skin [26]. Some exotic breeds such as Alpine (Benin), Anglo-Nubian, Toggenburg, Boer, Saanen (in Nigeria) and Majorera goat (Senegal) have been reported to be kept in West Africa Region under the traditional livestock system [27] [28].

The elevated temperature encounters in some Sub-Saharan African countries constitute a serious problem in goat keeping while the observed heat stress causes significant changes on behavioral, physiological and blood parameters via a reducing of feed intake, increasing of water consumption leading to weight loss [29] [30] [31]. The feeding system in West Africa countries based on the natural pastures, kitchen residues exposes animals to diseases that causes some important losses of the high reproductive performance [28]. In Southern African, farmers largely use the village goat management system [32].

Disease, parasite prevalence, limited forage availability, poor marketing management and low levels of management are one of the major constraints affecting goat productivity [32]. Reproductive and growth performance are influenced by the climates characteristics, production systems and goat breed raised in SSA region.

The level of goat reproduction performance depends on the interaction of genetic potential, environment and management [12]. The mean age at the first kidding which indicates the time of puberty was related to the environmental and genetic factor [12]. [33] demonstrated that the age of goat at the first kidding was 17.5, 15.5, 13.5 and 14.5 months respectively in semi-arid, sub-humid, humid and highland zone. In the Democratic Republic of Congo (Banza Ngungu district) goat has its adult body weight at the age of one year considered as the age for the first service. However, the buck attains the sexual maturity at five or six months. Three kidding were observed in two years and the multiple kidding depended on the rank of the litter [34]. Twins kidding were usually observed at the second kidding and the triplet at the sixth kidding with the probability of 
$6.8 \%$ on total number of the plain female. The gestation length of about 146 days with a reported range between 143 and 153 days was observed in goat populations in SSA [12]. In DR Congo, this period was for about 145 to 150 days [34]. Gestation periods of $141.3 \pm 4.6,143.5 \pm 3.2$ and $146.2 \pm 2.7$ days were reported in West African Draft Goat [35].

The weight of matures $(\mathrm{kg})$ does was found to be 29.7, 26.6, 25, 31.8 respectively in semi-arid, sub-humid, humid and highland zones in Sub-Saharan African region and 30.4, 29.2, 30.0 and $30.0 \mathrm{~kg}$ of body weight for matures bucks for the same zone respectively [23].

\section{Genetic Diversity of Goats in SSAR}

The genetic diversity characterization is essential for conservation strategy as well as for genetic improvement [36]. The genetic diversity characterization requires knowledge of genetic variation that can be affectively measured within and between populations. In principle, the genetic diversity can be measured based on polymorphism occurring at different levels: morphological, biochemical, cellular and DNA level [37]. Therefore, the investigation of genetic diversity at molecular level has been proposed as a valuable complement and sometimes proxy to phenotypic diversity of local breeds and is presently considered as one of the Food and Agriculture Organization's priorities for breed characterization.

The evolution of molecular biology has provided tools to determine the genetic diversity within and between animals, crops or microorganisms. Molecular markers are considered as one of the several powerful tools for the genomic analysis and permit the connection between hereditary traits and genomic variation. Single Nucleotide Polymorphisms (SNPs) and Simple Sequence Repeats (SSRs) or microsatellites are the most common type of DNA markers that have emerged to reveal the genetic diversity either for goat or other species [38] [39].

However, other markers have been used to study the genetic diversity of goat in different goat production systems around the world. Some of these molecular markers are Restriction fragment length polymorphism (RFLP) [40], Random amplification of polymorphic DNAs (RAPD) [41], Amplified fragment length polymorphisms (AFLP) [42].

The detection of signatures of selection has the potential to elucidate the identities of genes and mutations associated with phenotypic traits important for livestock species. It is also very relevant to investigate the levels of genetic diversity of a population, as genetic diversity represents the raw material essential for breeding and has practical implications for implementation of genomic selection.

Since goats are playing an important economic source of incomes (meat, milk, fiber, job) in developing countries including SSA countries, studying and maintaining of its genetic diversity in adaptive agro-ecological zones is very important.

Goat breeds from South-Saharan African zone were suggested to be divided 
into five major types [43] and the relationships between them could depend on the geographical locations. Due to the wide geographic, the diversify climate and the topography of the region, goats in SSA might have been isolated and affected by the natural pressure that could lead to their genetic differentiation [44] [45].

The genetic characterization of indigenous goats in Sub-Saharan African zone, including goats from eastern Africa (Maasai, Kigezi, Mubende, North West Highland, Arsi-Bale), southern Africa (Ndebele, Pafuri) and West Africa (West African Dwarf, Maure, Djallonke) using microsatellites markers revealed a huge variability within and between these populations [44]. Microsatellites markers revealed a genetic variability within the native goats in Cameroon according to agro-climatic patterns and husbandry systems [46]. A genetic variability indicated by the high minor number of alleles (MNA) and the expected heterozygosity recorded $(\mathrm{He})$ was observed in indigenous goat populations from Nigeria [47]. High genetic variability was observed in Small East Africa goat breed in Tanzania which implies a good score for their further improvement through selection within populations [48]. The analysis of the genetic diversity and phylogenetic structure in Mahabali goat population by mtDNA d-loop sequences revealed a total of six different monophylelic mtDNA haplogroups $\mathrm{A}, \mathrm{B}, \mathrm{C}, \mathrm{D}, \mathrm{F}$ and $\mathrm{G}$ with the haplogroup A representing $>90 \%$ of individuals [49]. Similar result was obtained by [50] suggesting that the highest proportion of the current studied domestic goat (90\%) based on mtDNA, belongs to haplogroup A which could not have changed dramatically in the expanding goat population since domestication could have dispersed more successfully, more often and more extensively than other domestic animals [14] [20].

The analysis of mtDNA and 50K SNP chip panel revealed a high level of genetic diversity, reported that only two (A and G) (Table 1) from six haplogroups globally identified were from Ethiopia and were compatible with observed haplogroups in Egyptian and Saudi Arabi goat populations suggesting common maternal history and the introduction of goats into East African and the Arabian

Table 1. Goat's haplogroups in some Sub-Saharan African goat populations.

\begin{tabular}{cccc}
\hline Country & Number of populations & Haplogroup & Author \\
\hline Ethiopia & 13 & A and G & {$[51]$} \\
Egypt & 26 & A and G & {$[15][51]$} \\
Nigeria & 12 & A & {$[15][51]$} \\
Namibia & 4 & A & {$[51]$} \\
Zimbabwe & 4 & A & {$[15][51]$} \\
Mozambique & 8 & A & {$[15][51]$} \\
Senegal & 3 & A & {$[15]$} \\
Tunisia & 6 & A & {$[15]$} \\
Libya & 1 & A & {$[51]$} \\
Algeria & 3 & A & {$[15]$} \\
Morocco & 6 & A & {$[15][51]$} \\
South Kivu/DRC & 1 & A and B & {$[52]$} \\
Kenya & 58 & A and G & {$[53]$} \\
Cameroon & 2 & A & {$[54]$} \\
\hline
\end{tabular}


Peninsula, respectively [51]. Goat from South Kivu in the eastern part of DRC was found to belong to the Haplogroup A and B [52] (Table 1).

\section{Candidate Genes Associated with Economic Traits in Goat}

To remain more important and contribute to the economy of farmers' households, goats should present more productive traits in terms of prolificacy, milk production, disease resistance, adaptability and other traits regarding their productivity. Improvement of goats in order to maintain and to boost expression of important traits needs a large knowledge on them [55]. For more African countries, goats are perceived to be a less risky to invest in compared to other species like sheep [56].

Accordingly, different studies have been conducted to identify genes associated with important traits either in goat or in other species. The functions of these genes are different once one of them has synergistic or antagonistic effects in nature for expression of phenotypic traits [55]. Different molecular biology techniques using molecular markers were used to investigate or to assess genes across goat's genome (whole genome sequencing or on a particular sequence across the genome); The whole genome was analyzed using 50K SNP chip to identify regions harboring genes associated with major traits and to determine the genetic diversity and the relationship within and between indigenous goat breeds [57].

A total of 271 candidate genes were detected in goats [55]. However, comprehensive investigations have been carried out on the polymorphism of some genes, involved in the control of economic traits included prolificacy or liter size, milk production, disease resistance, growth and fiber quality [58] [59] [60] [61].

\section{Candidate Genes Associated with Prolificacy in Goats in SSAR}

Many years have gone since research have been conducted by people with big interest to identify major or candidate genes associated with litter size in different goat populations. Many authors suggested the prolific particularities to be controlled by different genes in goat breeds [59] [60] [61], in sheep breeds [62] [63], and in cattle breeds [64]. Most of these genes were found in human genome, in cattle, in sheep and were suggested to induce defects in folliculogenesis and to be associated with prolificacy [65] (Table 2). In recent years, 4 natural genetic mutations have been identified and have been associated with ovulation rate in sheep breeds. Natural genetic mutations including one mutation (FecGH) in the Growth Differentiation Factor 9 gene (GDF 9), five different natural genetic mutations (FecXG, FecXB, FecXI, FecXH, FecXL) in the Bone Morphogenetic Protein 15 gene (BMP 15) and one natural genetic mutation (FecB) in the Bone Morphogenetic Protein Receptor type 1B gene (BMPR 1B) were investigated to detect the probably association with goat prolificacy [66]. Within the Indian goat breeds Black-Bengal; [67] revealed that a non-synonymous Single 
Table 2. Candidate genes and associated economic traits.

\begin{tabular}{ccc}
\hline Candidate genes & $\begin{array}{c}\text { Associated } \\
\text { economic traits }\end{array}$ & Author \\
\hline Bone morphogenetic protein15 (BMP 15) & Prolificacy & {$[59]-[71]$} \\
Bone morphogenetic protein receptor type-1B (BMPR 1B) & Prolificacy & {$[59]-[71]$} \\
Growth differentiation factor-9 (GDF 9) & Prolificacy & {$[59]-[71]$} \\
DiacylGlycerol AcylTransferase protein 1 (DGAT 1) & High milk yield & {$[69][73][74]$} \\
Signal Transducer and Activator of Transcription 5A (STAT 5A) & High milk yield & {$[69][73][74]$} \\
\hline
\end{tabular}

Nucleotide Polymorphism G1534A mutation in exon 2 of bone morphogenetic protein 4 was allied to variations seen in fecundity. Similarly, 2 homozygous SNPs (g.173057T >C, g. 151435C $>$ T) in exon 2 and the 3' untranslated region of prolactin receptor genes were discovered to be highly associated with prolificacy in Boer goat and Guanzhong breeds [68]. In the heterozygotes goats, high mutants of ovulation rates were detected in Bone Morphogenetic Protein 15 (BMP 15) whereas in the homozygous goats, mutants showed a failure of a primary ovarian rising in complete infertility [69] [70] [71].

In Sub-Saharan African region, studies were focused generally to evaluate reproductive performances of goat but not with an attention neither on the assessment of signatures of selection nor on candidate genes that can be in association with litter size or prolificacy. However, in Cameroon, it was mentioned that the genetic factors controlling twinning, triplet and quadruplet were related to the mutations in the Booroola gene and probably in GDF9 gene.

\section{Candidate Genes Associated with Milk Production in Goats in SSAR}

In 2010, results from several researchers show that India, Bangladesh, Sudan, Pakistan, France and Spain produced the higher levels of goat milk production, with $62.2 \%$ of the goat milk produced in the World. In Asia and Africa, the most of this produced goat milk is directly used for self-consumption, in Europe and Latino America minor quantity (proportion) is marketed as fresh liquid milk or transformed into candies or cheeses [72].

Milk production characters are more important in livestock production and for the economy and it's largely affected by a combination of factors namely; genetic make-up in terms of the use of improved breeds selected for milk production, a favorable nutritional environment and improved managerial practices. Milk can be evaluated for its safety, constituent contents, technological and organoleptic characteristics, nutritional, and functional properties. All these features are, to different extents, under genetic control [73] which may or may not be transferred to the offspring. The frequency and the polymorphism of two genes including DiacylGlycerol AcylTransferase1 (DGAT1) and Signal Transducers and Activators of Transcription type 5A (STAT 5A) were detected in association with goat milk production using molecular markers such as PCR-RFLP, 
PCR-SSCP and DNA sequencing (Table 2). Two probably natural mutations C1C1C3T3 and C1C2C3T3 were respectively detected in DGAT1 and STAT 5A and were reported to be in association with high milk production within two Chinese goat populations [69].

[74] assessed the genetic polymorphism and the association with milk production of kappa-casein gene in indigenous goat populations from five Eastern African countries including Kenya, Tanzania, Ethiopia, Sudan and Somalia. He demonstrated that among nine-point mutations corresponding to nine haplotypes identified in the exon 4 of kappa casein gene that only one haplotype $\left(\mathrm{CSN} 3{ }^{*} \mathrm{~B}\right)$ occurred at a rather high frequency $(0.750$ to 0.953$)$. Therefore, any of these nine points mutations in kappa casein gene could be associated with milk yield in indigenous Eastern Africa goat populations. According to these findings, there still a gap on the knowledge of signatures of selection or genomic regions associated with milk production trait in indigenous goats from SSAR.

\section{Conclusion}

Goats in SSAR are mostly raised in the traditional system. However little information regarding the signatures of selection or candidate genes associated with prolificacy and milk production within goat populations from many Sub-Saharan African countries is unknown. Agroecological zones have a great impact on the genetic variability among and between goat populations in Sub-Saharan African region suggesting that the genetic variability among and within them was determined by a wide geographic, the diversify climate and the topography. Within the six known worldwide goat's haplogroups, haplogroups A, B and G with the predominance of haplogroup A were found in goat population in SSAR. Different genes in association with prolificacy (GDF 9, BMP 15, BMPR 1B), and milk production (DGAT1, STAT 5A) were found in goat breeds in Europe, Asia and in America yet not assessed in Sub-Saharan Africa goat breeds.

\section{Conflicts of Interest}

The authors declare no conflicts of interest regarding the publication of this paper.

\section{References}

[1] Shrestha, J.N.B. and Fahmy, M.H. (2005) Breeding Goats for Meat Production: 2. Crossbreeding and Formation of Composite Population. Small Ruminant Research, 67, 93-112. https://doi.org/10.1016/j.smallrumres.2005.10.018

[2] Chentouf, M., Bister, J.L. and Boulanouar, B. (2011) Reproduction Characteristics of North Moroccan Indigenous Goats. Small Ruminant Research, 98, 185-188. https://doi.org/10.1016/j.smallrumres.2011.03.037

[3] Deldar-Tajangookeh, H., Shahneh, A.Z., Zamiri, M.J., Daliri, M., Kohram, H. and Nejati-Javaremi, A. (2009) Study of BMP-15 Gene Polymorphism in Iranian Goats. African Journal of Biotechnology, 8, 2929-2932.

[4] Ajmone-Marsan, P., Colli, L., Han, J.L., Achilli, A., Lancioni, H., Joost, S., Boettcher, 
P., et al. (2014) The Characterization of Goat Genetic Diversity: Towards a Genomic Approach. Small Ruminant Research, 121, 58-72. https://doi.org/10.1016/j.smallrumres.2014.06.010

[5] Mahmoudi, M., Rahnemaie, R., Soufizadeh, S., Malakouti, M.J. and Es-haghi, A. (2011) Residual Effect of Thiobencarb and Oxadiargyl on Spinach and Lettuce in Rotation with Rice. Journal of Agricultural Science and Technology, 13, 785-794.

[6] Mahrous, K.F., Saleha, Y.M., Alakilli, Lamiaa, M., Salem, S.H., Abd El-Aziem and El-Hanafy, A.A. (2013) Genetic Diversity in Egyptian and Saudi Goat Breeds Using Microsatellite Markers. Journal of Applied Biosciences, 72, 5838-5845. https://doi.org/10.4314/jab.v72i1.99671

[7] Akingbade, A., Nsahlai, I. and Morris, C. (2004) Reproductive Performance, Colostrum and Milk Constituents of Mimosine-Adapted South African Nguni Goats on Leucaena leucocephala-Grass or Natural Pastures. Small Ruminant Research, 52, 253-260. https://doi.org/10.1016/j.smallrumres.2003.07.003

[8] Zhang, X.-M., Wang, J.-Y. and Lan, Z.-R. (2012) Advances in Molecular Breeding Research of Goat Fecundity. Journal of Animal and Veterinary Advances, 11, 449-453. https://doi.org/10.3923/javaa.2012.449.453

[9] Alexandre, G., Arquet, R., Fleury, J., Troupé, W., Boval, M., Archimède, H., Mahieu, M. and Mandonnet, N. (2012) Systèmes d'élevage caprins en zone tropicale: analyse des fonctions et des performances. INRA Production Animals, 25, 305-316. https://doi.org/10.20870/productions-animales.2012.25.3.3218

[10] Palai, T.K., Bisoi, P.C., Maity, A., Behera, P.C., Sahoo, G., Polley, S. and De, S. (2013) Prolifiacy in Raighar Goats is Independent of FecB Gene. Veterinary World, 6, 479-481. https://doi.org/10.5455/vetworld.2013.479-481

[11] Feng, J. and Yang, W. (2015) Association between Ambient Air Pollution and Low Birth Weight in Southern Nevada. Nevada Journal of Public Health, 10, 21-30.

[12] Pamo, E.T., Boukila, B. and Tendonkeng, F. (2007) Goat Production Research in Africa: A Signpost Review for Research in the New Millenium. International Journal of Biological and Chemical Sciences, 1, 76-89. https://doi.org/10.4314/ijbcs.v1i1.39702

[13] Pereira, F. and Amorim, A. (2010) Origin and Spread of Goat Pastoralism. In: Encyclopedia of Life Sciences, John Wiley \& Sons, Hoboken. https://doi.org/10.1002/9780470015902.a0022864

[14] Fernández, H., Hugues, S., Vigne, J.D., Helmer, D., Hodgins, G.G., Miquel, C., Taberlet, P., et al. (2006) Divergent mtDNA Lineages of Goats in an Early Neolithic Site, Far from the Initial Domestication Areas. Proceedings of the Natural Academy of Sciences, 103, 15375-15379. https://doi.org/10.1073/pnas.0602753103

[15] Luikart, G., Fernández, H., Mashkour, M., England, P.R. and Taberlet, P. (2006) Origins and Diffusion of Domestic Goats Inferred from DNA Markers Example Analyses of mtDNA, Y Chromosome, and Microsatellites. In: Documenting Documentations. New Genetic and Archaeological Paradigms, University of California Press, Berkeley, Los Angeles, London, 294-305.

[16] Pereira, F., Queirós, S., Gusmão, L., Nijman, I.J., Cuppen, E., Lenstra, J.A., Econogene Consortium, Davis, S.J.M., Nejmeddine, F. and Amorim, A. (2009) Tracing the History of Goat Pastoralism: New Clues from Mitochondrial and Y Chromosome DNA in North Africa. Molecular Biology and Evolution, 26, 2765-2773. https://doi.org/10.1093/molbev/msp200

[17] Sultana, S., Mannen, H. and Tsuji, S. (2003) Mitochondrial DNA Diversity of Pakistani Goats. Animal Genetics, 34, 417-421. 
https://doi.org/10.1046/j.0268-9146.2003.01040.x

[18] Han, L., Yu, H.X., Cai, D.W., Shi, H.L., Zhu, H. and Zhou, H. (2010) Mitochondrial DNA Analysis Provides New Insights into the Origin of the Chinese Domestic Goat. Small Ruminant Research, 90, 41-46.

https://doi.org/10.1016/j.smallrumres.2009.12.011

[19] Mazdarani, F.H., Akbari, M.T., Fard, R.M.N., Hessari, M. and Pour, K.C. (2014) Molecular Identification of Capra hircus in East Chia Sabz, an Iranian Pre-Pottery Neolithic Site, Central Zagros, Based on mtDNA. The Journal of Animal \& Plant Sciences, 24, 945-950.

[20] Nomura, K., Yonezawa, T., Mano, S., Kawakami, S., Shedlock, A.M., Hasegawa, M. and Amano, T. (2013) Domestication Process of the Goat Revealed by an Analysis of the Nearly Complete Mitochondrial Protein-Encoding Genes, PLoS ONE, 8, e67775. https://doi.org/10.1371/journal.pone.0067775

[21] Boyazoglu, J., Hatziminaoglou, I. and Morand-Fehr, P. (2005) The Role of the Goat in Society: Past, Present and Perspectives for the Future. Small Ruminant Research, 60, 13-23. https://doi.org/10.1016/j.smallrumres.2005.06.003

[22] Escareño, L., Salinas-Gonàlez, H., Wurzinger, M., Iñiguez, L., SÖlkner, J. and Meza-Herrera, C. (2012) Dairy Goat Production Systems. Tropical Animal Health and Production, 45, 17-34. https://doi.org/10.1007/s11250-012-0246-6

[23] Otte, M.J. and Chilonda, P. (2002) Cattle and Small Ruminant Production Systems in Sub-Saharan Africa. A Systematic Review.

[24] Renault, V., Hambe, H.A., Van Vlaenderen, G., Timmermans, E., Mohamed, A.M., Ethgen, O. and Saegerman, C. (2019) Economic Impact of Contagious Caprine Pleuropneumonia and Cost-Benefit Analysis of the Vaccination Programmes Based on a One-Year Continuous Monitoring of Flocks in the Arid and Semi-Arid Lands of Kenya. Transboundary and Emerging Diseases, 66, 2523-2536. https://doi.org/10.1111/tbed.13317

[25] Wilson, R.T. (1991) Small Ruminant Production and Small Ruminant Genetic Resource in Tropical Africa. FAO, Rome, 231.

[26] Agossou, D.J., Dougba, T.D. and Koluman, N. (2017) Recent Developments in Goat Farming and Perspectives for a Sustainable Production in Western Africa. International Journal of Environment, Agriculture and Biotechnology, 2, Article ID: 238874. https://doi.org/10.22161/ijeab/2.4.62

[27] Asamoah, L. (2012) Country Pasture/Forage Resource Profiles, Liberia. FAO, Rome.

[28] Capote (2015) Environments and Goats around the World: Importance of Genetic and Management Factors. In: Kukovics, S., Ed., Sustainable Goat Breeding and Goat Farming in Central and Eastern, European Countries European Regional Conference on Goats, FAO, Rome, 1-16.

[29] Vissoh, D., Gbangboche, A.B. and Padonou, E. (2015) The Alpine Goat's Milk Production and Cheese Yield in Benin. International Journal of Current Research, 7, 22108-22112.

[30] Adedeji, T.A. (2012) Effect of Some Qualitative Traits and Non-Genetic Factors on Heat Tolerance Attributes of Extensively Reared West African Dwarf (WAD) Goats. International Journal of Applied Agriculture and Apiculture Research, 8, 68-81.

[31] Okoruwa, M.I. (2015) Effect of Coat Characteristics on Physiological Traits and Heat Tolerance of West African Dwarf Sheep in Southern Nigeria. Open Journal of Animal Sciences, 5, 351. https://doi.org/10.4236/ojas.2015.54039

[32] Baenyi, S.P., Birindwa, A.B., Mutwedu, V.B., Mugumaarhahama, Y., Munga, A., 
Mitima, B., Ayagirwe, R.B.B., et al. (2020) Effects of Coat Color Pattern and Sex on Physiological Traits and Heat Tolerance of Indigenous Goats Exposed to Solar Radiation. Journal of Animal Behavior and Biometeorology, 8, 142-151.

https://doi.org/10.31893/jabb.20017

[33] Gwaze, F., Chomonyo, M. and Dzama, K. (2009) Communal Goat Production in Southern Africa: A Review. Tropical Animal Health and Production, 41, 1157-1168. https://doi.org/10.1007/s11250-008-9296-1

[34] Sabimana, R.G., Simon, P.B. and Vumilia, R.K. (2018) Reproductive Parameters and Dynamic of Indigenous Goat Population in Mbanza-Ngungu District in the Democratic Republic of Congo. Revue délevage et de médecine vétérinaire des pays tropicaux, 70, 93-97. https://doi.org/10.19182/remvt.31522

[35] Oppong, E.N.W. and Yebuah, N.M.N. (1981) Some Production Traits of the West African Dwarf Goat. Tropical Animal Health and Production, 13, 208-212. https://doi.org/10.1007/BF02237927

[36] El-Sayed, M.A., El-Hamamsy, S.M., Abdelhamed, W. and El-danasoury, M.M. (2017) Genetic Diversity in Egyptian Goats Based on Microsatellite Markers. Cur rent Applied Science and Technology, 17, 130-139.

[37] Abdel-Mawgood, A.L. (2012) DNA Based Techniques for Studying Genetic Diversity. In: Genetic Diversity in Microorganisms, InTech, Rijeka, 95-122.

[38] Sunnucks, P. (2000) Efficient Genetic Markers for Population Biology. Trends in Ecology \& Evolution, 15, 199-203. https://doi.org/10.1016/S0169-5347(00)01825-5

[39] Yadav, A.K., et al. (2017) Antimicrobial Action of Methanolic Seed Extracts of Syzygium cumini Linn. on Bacillus subtilis. AMB Express, 7, 196.

https://doi.org/10.1186/s13568-017-0500-4

[40] Abdel-Aziem, S.H., Mahrous, K.F., Abd El-Hafez, M.A.M. and Mordy, M.A. (2018) Genetic Variability of Myostatin and Prolactin Genes in Popular Goat Breeds in Egypt. Journal of Genetic Engineering and Biotechnology, 16, 89-97. https://doi.org/10.1016/j.jgeb.2017.10.005

[41] Al-Barzinji, Y.M. and Humad, A.O. (2017) Characterization of Local Goat Breeds Using RAP-DNA Markers. AIP Conference Proceedings, 1888, Article ID: 020010. https://doi.org/10.1063/1.5004287

[42] Hoda, A., Sena, L. and Hykai, G. (2012) Genetic Diversity Revealed by AFLP Markers in Albanian Goat Breeds. Archives of Biological Sciences, 64, 799-807. https://doi.org/10.2298/ABS1202799H

[43] Rege, J.E.O., Yapi-Gnaore, C.V. and Tawah, C.L. (1996) The Indigenous Domestic Ruminant Genetic Resource.

[44] Chenyambuga, S.W., Hanotte, O., Hirbo1, J., Watts, P.C., Kemp, S.J., Kifaro, G.C., Gwakisa, P.S., Petersen, P.H. and Rege, J.E.O. (2004) Genetic Characterization of Indigenous Goats of Sub-Saharan Africa Using Microsatellite DNA Markers. Asian-Australian Journal of Animal Sciences, 17, 445-452. https://doi.org/10.5713/ajas.2004.445

[45] Muema, E.K., Wakhungu, J.W., Hanotte, O. and Jianlin, H. (2009) Genetic Diversity and Relationship of Indigenous Goats of Sub-Saharan Africa Using Microsatellite DNA Markers. Livestock Research for Rural Development, 21, 28.

[46] Félix, M., Francis, W., Jolly, N.E.P., Appolinaire, D. and Yacouba, M. (2014) Genetic Diversity of Cameroon Native Goat Populations Revealed by Caprine Microsatellites. Journal of Agricultural Science and Technology, 4, 706-713.

[47] Murital, I., Afolayan, O., Bemji, M.N., Dadi, O., Landi, V., Martínez, A., Delgado, 
J.V., Adebambo, O.A., Aina, A.B.J. and Adebambo, A.O. (2015) Genetic Diversity and Population Structure of Nigerian Indigenous Goat Using DNA Microsatellite Markers. Archivos de Zootecnia, 64, 93-98. https://doi.org/10.21071/az.v64i246.382

[48] Nguluma, A.S., Huang, Y., Zhao, Y., Chen, L., Msalya, G., Lyimo, C., Chenyambuga, S.W., et al. (2018) Assessment of Genetic Variation among Four Populations of Small East African Goats Using Microsatellite Markers. South African Journal of Animal Science, 48, 117-127. https://doi.org/10.4314/sajas.v48i1.14

[49] Mohammadi, S.B., Afshari, K.P. and Seyedabadi, H.R. (2018) Estimating the Distance of Genetic Domestic Goats in Iran Inferred from D-Loop Region of Mitochondrial DNA Analysis and Origins of Candidate Native Goat Ancestor. Animal Husbandry, Dairy and Veterinary Science, 2, 1-6.

https://doi.org/10.15761/AHDVS.1000139

[50] Naderi, S., Rezaei, H.R., Pompanon, F., Blum, M.G., Negrini, R., Naghash, H.R., Kence, A., et al. (2008) The Goat Domestication Process Inferred from Large-Scale Mitochondrial DNA Analysis of Wild and Domestic Individuals. Proceedings of the National Academy of Sciences, 105, 17659-17664. https://doi.org/10.1073/pnas.0804782105

[51] Tarekegn, G.M., Tesfaye, K., Mwai, O.A., Djikeng, A., Dessie, T., Birungi, J., Tutah J., et al. (2018) Mitochondrial DNA Variation Reveals Maternal Origins and Demographic Dynamics of Ethiopian Indigenous Goats, Ecology and Evolution, 8, 1543-1553. https://doi.org/10.1002/ece3.3710

[52] Bwihangane, B.A., Gitao, G.C., Bebora, L.C., Tarekegn, M.G., Nicholas, S., Bacigale, S. and Svitek, N. (2018) Mitochondrial DNA Variation of Indigenous Goat Populations from Peste-des-petits-ruminants Outbreak in South Kivu, Democratic Republic of the Congo. Livestock Research for Rural Development, 30, 18.

[53] Kibegwa, F.M., Githui, K.E., Jung'a, J.O., Badamana, M.S. and Nyamu, M.N. (2016) Mitochondrial DNA Variation of Indigenous Goats in Narok and Isiolo Counties of Kenya. Journal of Animal Breeding and Genetics, 133, 238-247. https://doi.org/10.1111/jbg.12182

[54] Tarekegn, G.M., Wouobeng, P., Jaures, K.S., Mrode, R., Edea, Z., Liu, B., Strandberg, E., et al. (2019) Genome-Wide Diversity and Demographic Dynamics of Cameroon Goats and Their Divergence from East African, North African, and Asian Conspecifics. PLoS ONE, 14, e0214843. https://doi.org/10.1371/journal.pone.0214843

[55] China Supakorn (2009) The Important Candidate Genes in Goats-A Review. Walailak Journal of Science and Technology, 6, 17-36.

[56] Dossa, L.H., Rischkowsky, B., Birner, R. and Wollny, C. (2007) Socio-Economic Determinants of Keeping Goats and Sheep by Rural People in Southern Benin. Agricultural and Human Values, 25, 581-592. https://doi.org/10.1007/s10460-008-9138-9

[57] Rahmatalla, S.A., Arends, D., Reissmann, M., Ahmed, A.S., Wimmers, K., Reyer, H. and Brockmann, G.A. (2017) Whole Genome Population Genetics Analysis of Sudanese Goats Identifies Regions Harboring Genes Associated with Major Traits. BMC Genetics, 18, 92. https://doi.org/10.1186/s12863-017-0553-Z

[58] Amills, M. (2014) The Application of Genomic Technologies to Investigate the Inheritance of Economically Important Traits in Goats. Advances in Biology, 2014, Article ID: 904281. https://doi.org/10.1155/2014/904281

[59] Chu, M.X., Jiao, C.L., He, Y.Q., Wang, J.Y., Liu, Z.H. and Chen, G.H. (2007) Association between PCR-SSCP of Bone Morphogenetic Protein 15 Gene and Prolificacy 
in Jining Grey Goats. Animal Biotechnology, 18, 263-274.

https://doi.org/10.1080/10495390701331114

[60] Ran, X.Q., Lin, J.B., Du, Z.Y., Qing, C. and Wang, J.F. (2009) Diversity of BMP15 and GDF9 Genes in White Goat in Guizhou Province and Evolution of the Encoded Proteins. Zoological Research, 30, 593-602.

https://doi.org/10.3724/SP.J.1141.2009.06593

[61] Abdel-Rahman, S.M., Mustafa, Y.A., Abd Errasool, H.A., El-Hanafy, A.A. and Elmaghraby, A.M. (2013) Polymorphism in BMP-15 Gene and Its Association with Litter Size in Anglo-Nubian Goat. Biotechnology in Animal Husbandry, 29, 675-683. https://doi.org/10.2298/BAH1304675A

[62] Hanrahan, P.J., Gregan, S.M., Mulsant, P., Mullen, M., Davis, G.H., Powell, R. and Galloway, S.M. (2004) Mutations in the Genes for Oocyte-Derived Growth Factors GDF9 and BMP15 Are Associated with Both Increased Ovulation Rate and Sterility in Cambridge and Belclare Sheep (Ovis aries). Biology of Reproduction, 70, 900-909. https://doi.org/10.1095/biolreprod.103.023093

[63] Davis, G.H. (2005) Major Genes Affecting Ovulation Rate in Sheep. Genetics Selection Evolution, 37, 11-23. https://doi.org/10.1186/1297-9686-37-S1-S11

[64] Öztabak, K., Toker, N.Y., Ün, C. and Akiş, I. (2010) Leptin Gene Polymorphism in Native Turkish Cattle Breeds. Kafkas Üniversitesi Veteriner Fakültesi Dergisi, 16, 921-924.

[65] Vitt, U.A. and Hsueh, A.J. (2001) Stage-Dependent Role of Growth Differentiation Factor-9 in Ovarian Follicle Development. Molecular and Cellular Endocrinology, 186, 211-217. https://doi.org/10.1016/S0303-7207(01)00614-1

[66] Wang, Y., Yuanxiao, L., Nana, Z., Zhanbin, W. and Junyan, B. (2011) Polymorphism of Exon 2 of BMP15 Gene and Its Relationship with Litter Size of Two Chinese Goats. Asian-Australian Journal of Animal Sciences, 24, 905-911. https://doi.org/10.5713/ajas.2011.10432

[67] Sharma, R., Ahlawat, S., Maitra, A., Roy, M., Mandakmale, S. and Tantia, M.S. (2013) Polymorphism of BMP4 Gene in Indian Goat Breeds Differing in Prolificacy. Gene, 532, 140-145. https://doi.org/10.1016/j.gene.2013.08.086

[68] An, X.P., Ma, T., Hou, J., Fang, F., Han, P., Yan, Y., Zhao, H., Song, Y., Wang, J. and Cao, B. (2013) Association Analysis between Variants in KISS1 Gene and Litter Size in Goats. BMC Genetics, 14, 63. https://doi.org/10.1186/1471-2156-14-63

[69] Galloway, S.M., McNatty, K.P., Cambridge, L.M., Laitinen, M.P.E., Juengel, J.L., Jokiranta, T.S., McLaren, R.J., Luiro, K., Dodds, K.G., Montgomery, G.W., Beattie, A.E., Davis, G.H. and Ritvos, O. (2000) Mutations in an Oocyte-Derived Growth Factor Gene (BMP15) Cause Increased Ovulation Rate and Infertility in a Dosage-Sensitive Manner. Nature, 25, 279-283. https://doi.org/10.1038/77033

[70] Bodin, L., Di Pasquale, E., Fabre, S., Bontoux, M., Monget, P., Persani, L. and Mulsant, P. (2007) A Novel Mutation in the Bone Morphogenetic Protein 15 Gene Causing Defective Protein Secretion Is Associated with Both Increased Ovulation Rate and Sterility in Lacaune Sheep. Endocrinology, 148, 393-400. https://doi.org/10.1210/en.2006-0764

[71] Monteagudo, L.V., Ponz, R., Tejedor, M.T., Lavina, L. and Sierra, I. (2009) A 17 bp Deletion in the Bone Morphogenetic Protein 15 (BMP15) Genes Is Associated to Increased Prolificacy in the Rasa Aragonesa Sheep Breed. Animal Reproduction Science, 110, 139-146. https://doi.org/10.1016/j.anireprosci.2008.01.005

[72] Miller, B.A. and Lu, C.D. (2009) Current Status of Global Dairy Goat Production: An Overview. Asian-Australasian Journal of Animal Sciences, 32, 1219. 
https://doi.org/10.5713/ajas.19.0253

[73] Pilla, L., Patuzzo, R., Rivoltini, L., Maio, M., Pennacchioli, E., Lamaj, E., Tosi, D., et al. (2006) A Phase II Trial of Vaccination with Autologous, Tumor-Derived Heat-Shock Protein Peptide Complexes Gp96, in Combination with GM-CSF and Interferon- $\alpha$ in Metastatic Melanoma Patients. Cancer Immunology, Immunotherapy, 55, 958. https://doi.org/10.1007/s00262-005-0084-8

[74] Kiplagat, S.K., Agaba, M., Kosgey, I.S., Okeyo, M., Indetie, D., Hanotte, O. and Limo, M.K. (2010) Genetic Polymorphism of Kappa-Casein Gene in Indigenous Eastern Africa Goat Populations. International Journal of Genetics and Molecular Biology, 2, 1-5. 